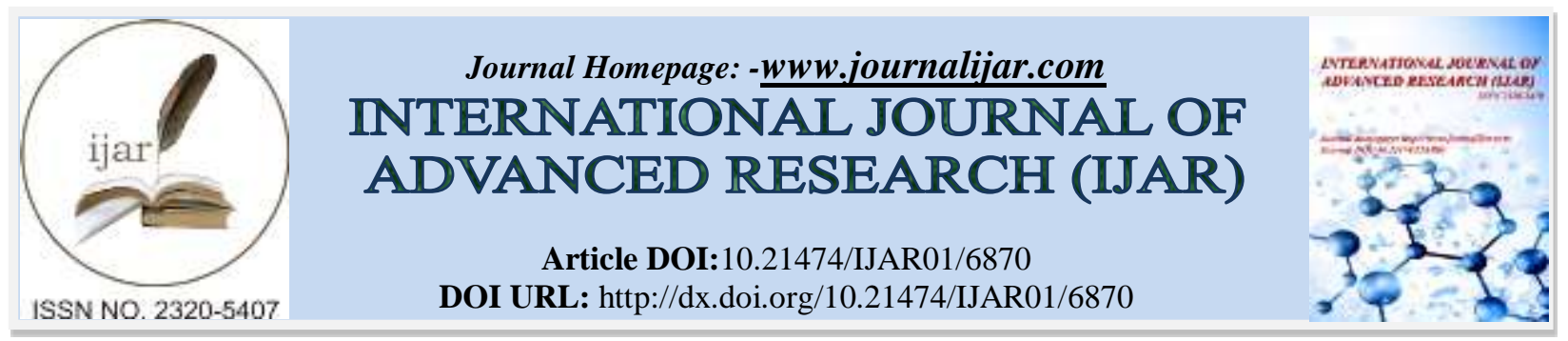

RESEARCH ARTICLE

\title{
JURIDICAL REVIEW ON THE FULFILLMENT OF DISTRICT HEAD POSITION.
}

\author{
Tuti Hardiyanti ${ }^{1}$, Marwati Riza ${ }^{2}$ and Zulkifli Aspan ${ }^{2}$. \\ 1. Graduate School, Faculty of Law, Hasanuddin University. \\ 2. Faculty of Law, Hasanuddin University.
}

\section{Manuscript Info}

Manuscript History

Received: 07 February 2018

Final Accepted: 09 March 2018

Published: April 2018

Keywords:-

District Head, Position, Position and

Despise Agency, Regional Personnel Officer.

\begin{abstract}
Based on Article 224 paragraph (2) of Law Number 23 Year 2014 on Regional Government stipulates that Regent/Mayor shall appoint district heads of civil servants who master government technical knowledge and meet employment requirements in accordance with the provisions of legislation. Furthermore, in the elucidation of Article 224 paragraph (2) of Law Number 23 Year 2014 on Regional Government stipulates that what is meant by mastering the technical knowledge of government is proved by diploma certificate/bachelor of government science. Furthermore, in Article 24 of Government Regulation Number 19 Year 2008 regarding the district head regulates that the district head is appointed by the Regent/Mayor at the suggestion of the district/city secretary of the civil servant who holds the technical knowledge of the government and meets the requirements in accordance with the laws and regulations. Based on the results of research conducted revealed that the series of stages filling the district head position has been implemented well that is started by completing the list of candidates for district head. After the list of candidates for the district head is completed, the Bureau of Personnel conducts an examination of the terms of position and set forth in the form of a Councils of Position and Branch Considerations. Furthermore, the Office of Consideration of Position and Department held a meeting to discuss the issue of competence, seniority of rank, training and positions of experience. The result of the meeting of the Office of Consideration of Position and the Bureau shall be submitted in writing to the Regional Personnel Officer in the form of determining the order of the three selected candidates, then Regent shall choose one of them to make a decision letter. However, the fact that of the three proposed candidates, the officers of the regional civil service manager did not approve it, the Regent proposed to the Office of Consideration of Position and the rank to review again.

Copy Right, IJAR, 2018,. All rights reserved.
\end{abstract}

\section{Introduction:-}

Indonesia is a law-based country as affirmed in Article 1 paragraph (3) of the 1945 Constitution of the State of the Republic of Indonesia. The legal state is a state whose administration of power is based on law. The government in carrying out any action must be based on law and be legally accountable. The role of law in regulating the life of 
society has been known since people know the law itself, because the law was made to regulate human beings as social beings. The relationship between society and the law is expressed in the adage of "ubi societas ibi ius" (where there is a society there is a law). ${ }^{1}$ This shows that law is an important element for people's lives, not least in the Unitary State of the Republic of Indonesia.

Indonesia is a country with welfare state concept. The main characteristic of this country is the emergence of the government's obligation to realize the common prosperity for the community. In creating prosperity and prosperity for society, the administration of government must be in accordance with what has been aspired. The government has the authority and responsibility to run the government and provide services to the community for the realization of the welfare of society and the implementation of democratic governance. In the context of government, the needs of the community are the demands and responsibilities of the government. The government has the role and function of providing services to meet the needs of the community.

During this time of reform, efforts to realize a democratic, clean and authoritative system of government have been a top priority for the Indonesian government. ${ }^{2}$ One of the reform efforts is to place the right people or apparatus in filling the position in the government structure (the right man on the right place). That is, the leader must be able to choose people who have the competence and place it in positions in accordance with its competence.

Competence is an ability to perform or perform a job or task based on skills and knowledge and supported by the work attitude required by the job. ${ }^{3}$ Thus, competence shows the skills or knowledge characterized by professionalism in a particular field as something important.

The purpose of the state life to be achieved as defined in the fourth paragraph of the Preamble of the 1945 Constitution of the State of the Republic of Indonesia shall involve the civil state apparatus in performing the highly complex tasks, the extent of its scope, and entering all sectors of life.

Human resources become one of the most important components in achieving the national goals of the Indonesian nation. State civil apparatus in this district head is one part of human resources that must be owned by a country to be able to run the wheels of government for the achievement of the purpose of nation and state. The District head serves as a public servant who performs a fair service, maintaining the unity and integrity of the nation with full loyalty to Pancasila and the Constitution of the State of the Republic of Indonesia Year 1945. Therefore, in line with the objective to realize the implementation of government and development duties, head professional and responsible.

Submission of district head positions by juridical has been elaborated in Law Number 5 Year 2014 on State Civil Apparatus, Government Regulation Number 11 Year 2017 on Civil Servant Management and also regulated in Law Number 23 Year 2014 on Regional Government. In addition, the filling of district head positions must be in accordance with Government Regulation Number 19 Year 2008 regarding the district head.

According to Article 68 paragraph (2) of Law Number 5 of 2014 on State Civil Apparatus provides that the appointment of civil servants in a particular position is determined on the basis of an objective comparison between the competence, qualifications and requirements required by a position with the competence, qualifications and requirements owned by employees. ${ }^{4}$

According to Article 131 of Law Number 5 of 2014 on the State Civil Apparatus provides that the echelon III (district head) office is equivalent to the position of administrator.

According to Article 54 paragraph (1) of Government Regulation Number 11 of 2017 concerning the Management of Civil Servants provides that the requirements to be appointed in the office of administrators are as follows: ${ }^{5}$

1. Must be Civil Servants

1 Satjipto Rahardjo, 1983, Masalah Penegakan Hukum, Bandung, Penerbit Sinar Baru, hlm. 127.

2 Sri Hartini, 2010, Hukum Kepegawaian di Indonesia, Jakarta, Sinar Grafika, hlm. 5.

3 Wibowo, 2012, Manajemen Kinerja, Jakarta, Rajawali Pers, hlm. 324.

4 Article 68 of Law Number 5 Year 2014 on State Civil Apparatus

5 Article 54 paragraph (1) of Government Regulation Number 11 of 2017 on the Management of Civil Servants 
2. Have the lowest education qualification and degree or diploma IV

3. Have good integrity and morality

4. Each element of performance appraisal is at least worth well in the last 2 (two) years

5. Have technical competence, managerial competence, and cultural social competence according to competency standard proven based on evaluation result by performance appraisal team of civil servant in institution.

6. Physically and mentally healthy

Furthermore, in Article 55 paragraph (1) of Government Regulation Number 11 Year 2017 concerning Civil Servant Management stipulates that the competence of administrator position, supervisory office and executing office as referred to in Article 54 paragraph (1) letter e, paragraph (3) letter f, and paragraph (4) letter e includes technical competence, managerial competence, and cultural social competence.

According to Article 224 paragraph (2) of Law Number 23 Year 2014 on Regional Government stipulates that Regent/Mayor shall appoint district heads of civil servants who master government technical knowledge and meet employment requirements in accordance with the provisions of the Laws and Regulations. Furthermore, in the elucidation of Article 224 paragraph (2) of Law Number 23 Year 2014 on Regional Government stipulates that what is meant by mastering the technical knowledge of government is proved by diploma certificate/bachelor of government science. ${ }^{6}$

According to Article 24 of Government Regulation Number 19 Year 2008 regarding the District Head provides that the district head shall be appointed by the Regent/Mayor at the suggestion of the district/city secretary of the civil servant who holds the technical knowledge of the government and meets the requirements in accordance with the laws and regulations. Furthermore, in Article 25 of Government Regulation Number 19 Year 2008 concerning the District Head stipulates that government technical knowledge covers:

1. Mastering the field of governmental science is evidenced by diploma/graduate diploma of government.

2. Have served in the village, urban village, or district head for a minimum of 2 (two) years.

Law Number 23 of 2014 on Regional Government provides that the district head is no longer a unit of governmental territory, but as a unit of work or service. The status of district head is now a regency/municipal apparatus described in Article 209 paragraph (2) of Law Number 23 Year 2014 on Regional Government namely, "Regency/City regional apparatus comprising of regional secretariat, secretariat of Regional House of Representative, Agency, and District Head".

The District head is no longer a head of the district head and as a tool of the central government in carrying out deconcentrated tasks but has become a regional apparatus with some autonomous regional authority and governance arranged in Law Number 23 of 2014 on Regional Government. The district head institution in its position as a regional apparatus is the spearhead of the regional government that oversees the villages and villages in providing services to the community and implementing the development. Since district heads are the spearheads that directly come into contact with society's problems, poor professionalism of employees at district head level will affect the image of service in the eyes of society in general.

One of the reform agenda in tune with the spirit of regional autonomy is the renewal of government both at the central and in the regions. Article 18 Paragraph (1) of the 1945 Constitution of the State of the Republic of Indonesia stipulates that the Unitary State of the Republic of Indonesia is divided over the provinces, districts and municipalities having local government. Bureaucracy reform is not only held in the central government but with the trigger of the principle of regional autonomy, bureaucracy reform also takes place in local government.

Nevertheless, behind all efforts made by the government by trying to streamline the existing bureaucratic level, including by adopting the concept of good governance but not yet fully able to guarantee the implementation of a good governance. In fact there are still many practices found in the administration of deviant.

6 Article 224 of Law Number 23 Year 2014 on Regional Government 
These problems are caused by the knowledge and understanding of the government apparatus on the concept of good governance is not sufficient. In a sense, that the disclosure of the concept doesn't take into account the capacity and capacity of the government apparatus, so that the implementation of the concept of good governance is not running as expected. The problem of filling the district head position is a very complex issue considering the regulation on filling the district head position is regulated in legislation. To that end, the central and local governments must be able to interpret the rules appropriately and consistently.

District head filling is done by taking into account the factors of education and training of positions, competencies, and tenure of a district head since the first appointment in a particular position up to retirement. Article 224 of Law Number 23 Year 2014 concerning Regional Government stipulates that the requirements of a civil servant occupying the head of district positions shall be in the area of governmental science proven by diploma/graduate degree in governmental sciences. Concerning the implementation of the concept of employee placement, especially for the context of Indonesia to date is still far from expectations. This assumption then arises with the fact that almost in some local governments to this day both the provincial and district/city governments have not placed their employees in the ideal position or on the type of work appropriate to their level of expertise, education, and competence.

Based on the problems that occurred, the authors suspect that the filling of the district head position in Sinjai District conducted by the Personnel and Human Resource Development Office of the Apparatus has not fully pursued the mechanism in accordance with the provisions of the prevailing laws and regulations. This is due to the growing culture within government organizations still prioritizing personal closeness with superiors, so that the district head's competence and capacity become neglected. One of the reform efforts is to place the right people or apparatus in filling the position in the government structure (the right man on the right place).

So far we know the merit system among the bureaucracy. This system emphasizes the skills of a civil state apparatus including the district head in filling the position, because the basis of consideration of skills assessed objectively, the standard size used is the education certificate. That is why the district head candidate who will be appointed should master the technical knowledge of government as evidenced by diploma/government science degree. This is certainly a bit influential in carrying out its duties and functions of implementing some regional autonomy affairs and duties of government well. Based on the above background description, the authors will analyze whether the filling of the district head position in Sinjai District is in accordance with the terms of the position stipulated in the legislation. So the title raised in this study is the Juridical Review of District Head Filling.

\section{Method of the Research:-}

This research is empirical law research that is to test the legislation and see the realization of Laws and Regulations. The authors chose the location of research in the Personnel and Human Resource Development Agency Apparatus Sinjai District. The selection of the location is based on the consideration that the Human Resources Personnel and Human Resource Development Office of Sinjai Regency is considered representative enough to obtain the required data. Population in this research is all employee in Personnel Board and Human Resource Development Apparatus of Sinjai Regency. Meanwhile, the sample in this study is the Head of Human Resources and Human Resource Development Office of Sinjai District Apparatus and 2 employees in the Human Resources and Human Resource Development Agency of Sinjai District Apparatus.

The type and data source used is primary data that is data obtained directly from the first source (respondent) at the research location. In addition, secondary data is data obtained through library research both with techniques of collecting and inventory of books, scientific papers, and documents. The data collection is done by interviewing the authors held question and answer with the parties directly related to the issues discussed, the documentation of the authors take the data by observing documents and archives provided by related parties, as well as literature study of the authors collecting data to collect data from the various required literature related to the issues discussed.

\section{Results and Discussion:-}

\section{Charging Position District Head in Sinjai District:-}

The district head is a District/City District Device that has a specific working area, headed by a district head and is responsible to the Regent/Mayor through the district/city secretary who implements some regional autonomy and government duties. The functioning of the district head in carrying out the task will depend on how big the delegation of authority given by the Regent/Mayor. The district head has the duty and function of exercising the 
authority delegated by the Regent/Mayor in accordance with the characteristics of the region, regional needs and other governmental functions based on the legislation. This delegation of authority is actually an attempt to optimize the district head's function and function in the framework of governance, regional development, and service to the community.

The policy of delegation of authority of Regent / Mayor to district head is regulated in Article 226 of Law Number 23 Year 2014 regarding Regional Government as follows : ${ }^{7}$

1. In addition to performing the duties as referred to in Article 225 paragraph (1), the district head shall obtain a transfer of part of the Regent/Mayor's authority to exercise some of the governmental affairs under the authority of the Regency/City.

2. The delegation of Regent/Mayor authority referred to in paragraph (1) shall be based on mapping of public services in accordance with the characteristics of district head and/or community needs in the respective district head.

3. The delegation of Regent/Mayor authority as referred to in paragraph (2) shall be stipulated by Regent/Mayor Decree based on Government Regulation.

The policy of delegation of Regent authority to district head in Sinjai Regency is regulated in Local Regulation Number 20 Year 2010 concerning Organization and Administration of District Head and Sub-District of Sinjai Regency. Civil servants including the district head in the duty of civil apparatus of the state shall be appointed in positions where the principle of filling the position shall be in accordance with competence, rank, and other objective conditions without distinction of sex, race, religion, race and class. This implies that the district head in carrying out its main duties and functions must be placed in a position in accordance with the terms of office in question, so that it can carry out its responsibilities in accordance with the positions held.

According to Article 68 paragraph (2) of Law Number 5 of 2014 on State Civil Apparatus provides that the appointment of civil servants in a particular position is determined on the basis of an objective comparison between the competence, qualifications and requirements required by a position with the competence, qualifications and requirements owned by employees. ${ }^{8}$ According to Article 224 paragraph (2) of Law Number 23 Year 2014 on Regional Government stipulates that Regent/Mayor shall appoint district heads of civil servants who master government technical knowledge and meet employment requirements in accordance with the provisions of the Laws and Regulations. Furthermore, in the elucidation of Article 224 paragraph (2) of Law Number 23 Year 2014 on Regional Government stipulates that what is meant by mastering the technical knowledge of government is proved by diploma certificate / bachelor of government science. ${ }^{9}$

According to Article 69 paragraph (3) of Law Number 5 Year 2014 on State Civil Apparatus stipulates that the competence referred to paragraph (1) covers : ${ }^{10}$

1. Technical competencies measured from the level and specialization of education, functional technical training, and technical work experience.

2. Managerial competence as measured by level of education, structural or management training, and leadership experience.

3. Cultural social competence as measured by work experience relates to pluralistic societies in terms of religion, ethnicity and culture, so as to have national insight.

According to Mr. Firdaus ${ }^{11}$ that:

"The filling of the district head positions should pay attention to the competencies. The competence can be seen from his educational background, experience, and managerial training".

7 Article 226 of Law Number 23 Year 2014 on Regional Government

8 Article 68 of Law Number 5 Year 2014 on State Civil Apparatus

9 Article 224 of Law Number 23 Year 2014 on Regional Government

${ }^{10}$ Article 69 of Law Number 5 Year 2014 on State Civil Apparatus

${ }^{11}$ Secretary of the Regional Personnel and Resources Development Agency of Sinjai District, the interview was held on February 9, 2018 at the Office of the Personnel and Resource Development Agency of Sinjai District. 
The same thing was also expressed by Mr. Ashari ${ }^{12}$ said that : "The conditions under which a person is appointed to the district head are the rank, formal education, leadership training and technical training that has been followed, and the experience of the employee who will be appointed as the district head because it will affect the performance of the position he will occupy".

From the above interviews it can be analyzed that a person who is appointed to be a district head must meet the required competencies consisting of the level of knowledge seen from the educational background, the level of expertise seen from the training followed and the work experience that can be seen from the experience occupy previous positions and length of work referring to rank and class.

The filling of the district head position in Sinjai Regency is guided by Government Regulation Number 100/2000 on the Appointment of Civil Servants in Structural Positions. Article 5 affirms the requirement for the appointment of civil servants in structural positions :

1. Must be Civil Servants

2. At the very least occupy the rank of 1 (one) level below the determined level of rank.

3. Have the qualifications and level of education specified.

4. All elements of the performance appraisal are at least of good value in the last 2 (two) years.

5. Have the required job competence

6. Physically and mentally healthy, and need to consider the factors of education and training positions, and experience owned.

7. A civil servant who will or has been in a structural position must follow and pass leadership education and training in accordance with the competencies set forth for the post.

In addition, Government Regulation Number 19 Year 2008 on the District Head requires a district head to master government technical knowledge. Furthermore, in Article 25 of Government Regulation Number 19 Year 2008 concerning the District Head stipulates that government technical knowledge covers : ${ }^{13}$

1. Mastering the field of governmental science is evidenced by diploma/graduate diploma of government.

2. Have served in the village, urban village, or district head for a minimum of 2 (two) years.

The conditions for occupying the district head office will be described as follows :

\section{Government Technical Education:-}

Education is one of the most important conditions in filling the district head position because education is the basis/foundation of knowledge formally. The district head is a regional apparatus of a Regency as a regional technical implementer having a certain working area and is headed by a district head. In Sinjai District there are 9 district heads: North Sinjai District Head, East Sinjai, South Sinjai, West Sinjai, Sinjai Borong, Bulupoddo, Sinjai Tengah, Tellulimpoe, and Sembilan Island.

According to Mr. Firdaus ${ }^{14}$ that : "Education is very important and absolutely necessary for every civil servant especially for district head position because basically someone who appointed as district head must have equal education, that is master of education of governmental science and have served in village/district head for two years.

\section{Leadership Training:-}

The level of knowledge and understanding of district head in Sinjai District is not only obtained through formal education but also can be obtained through the development of insights with special education or commonly called non-formal education which is usually implemented in the form of training. Leadership training is a training program intended for civil servants to occupy structural positions. This matter is regulated in Government Regulation Number 101 Year 2000 about Education and Training of Position of Civil Servant. Civil Servants in this

12 Head of Sub Division of Mutation and Departement of Personnel Board and Resource Development of Regional Apparatus of Sinjai Regency, the interview was held on February 5, 2018 at the Office of Personnel and Development of Regional Apparatus Resources of Sinjai Regency.

13 Article 25 of Government Regulation Number 19 Year 2008 regarding the district head

14 Secretary of the Human Resources Personnel and Human Resource Development Office of Sinjai District, the interview was held on February 9, 2018 at the Office of Human Resources and Human Resource Development Agency of Sinjai District Apparatus. 
district head must have a competence that is identified with attitudes and behaviors that are full of loyalty and obedience as a public servant, and able to become a glue of unity and national unity.

The rationale of training policy stipulated in Government Regulation Number 101 of 2000 is as follows :

1. Training is an integral part of civil service guidance system.

2. The education and training program is related to the career development of civil servants.

3. The training system covers the process of identifying needs, planning, organizing, and evaluating the training.

4. The training is directed to prepare civil servants in order to meet the prescribed job requirements and organizational needs, including the procurement of leadership cadres and staff.

To form the civil servants as above, it is necessary that the training leads to :

1. Increased attitude and spirit of dedication that is oriented to the interests of society, nation, country, and country.

2. Increased technical competence, managerial, and leadership.

3. Improved efficiency, effectiveness, and quality of tasks carried out in a spirit of cooperation and responsibility in accordance with the work environment and organization.

Training consists of two functions, namely the function of education and training functions which is an integral whole. In accordance with national demands and global challenges to achieve good governance, it is necessary human resources apparatus that has the competence of office in state administration and development. To create human resources apparatus that have the competence is required to improve the quality of professionalism, attitude and devotion to the struggle of the nation and state, the spirit of unity and unity, and the development of civil servant insight through education and training positions that are an integral part of the business development of employees a comprehensive civilian country. Education and training of civil servant position referring to the competence of office.

Participation in leadership training should be prioritized for civil servants who have been appointed in structural positions but have not followed and passed leadership training in accordance with the occupation of structural positions. The data list of district head names that have followed the leadership training III obtained in the Office of Personnel and Human Resource Development Apparatus Sinjai District is as follows :

Table 1:- List of Head District Names Following PIM Training III.

\begin{tabular}{|l|l|l|}
\hline \multicolumn{1}{|c|}{ Number } & \multicolumn{1}{|c|}{ Districts } & \multicolumn{1}{c|}{ Head of District Name } \\
\hline 1. & North Sinjai District & $\begin{array}{l}\text { A. Irwansyahrani Yusuf,S.STP } \\
\text { Nip. 19780107 199612 10 02 }\end{array}$ \\
\hline 2. & South Sinjai District & $\begin{array}{l}\text { Agus Salam,S.STP } \\
\text { Nip. 19810813 199912 1001 }\end{array}$ \\
\hline 3. & East Sinjai District & $\begin{array}{l}\text { Tamzil Binawan,AP, M.Si } \\
\text { Nip. 19730611 199311 1 002 }\end{array}$ \\
\hline 4. & District Buluopoddo & $\begin{array}{l}\text { Hj. Andi Hariyani Rasyid,S.Sos,MM } \\
\text { Nip. 19651231 198503 2 024 }\end{array}$ \\
\hline 5. & District of Tellulimpoe & $\begin{array}{l}\text { Abdul Rahman } \\
\text { Nip. 19650130 199302 1 002 }\end{array}$ \\
\hline 6. & District of Sembilan Island & $\begin{array}{l}\text { A. Adityawarman Atma Poetra,S.STP } \\
\text { Nip. 19870514 200602 1 002 }\end{array}$ \\
\hline 7. & District of Sinjai Tengah & $\begin{array}{l}\text { Muhammad Dahlan,S.Pd } \\
\text { Nip. 19600320 198603 1 013 }\end{array}$ \\
\hline
\end{tabular}

Source: Office of Personnel and Human Resource Development Apparatus Sinjai District, 2018

The data list of district head names that have not followed the leadership training III obtained in the Office of Personnel and Human Resource Development Apparatus Sinjai District is as follows:

Table 2:-List of Head District Names that Have Not Followed PIM Training III

\begin{tabular}{|c|l|l|}
\hline Number & \multicolumn{1}{|c|}{ Districts } & \multicolumn{1}{|c|}{ Head of District Name } \\
\hline 1. & West Sinjai District & A. Paris, AKS \\
& & \multicolumn{1}{|c|}{ Nip. 196212311987031189 } \\
\hline
\end{tabular}




\begin{tabular}{|l|l|l|}
\hline 2. & District of Sinjai Borong & $\begin{array}{l}\text { Zainal } \\
\text { Nip. } 196012311992031083\end{array}$ \\
\hline
\end{tabular}

Source: Office of Personnel and Human Resource Development Apparatus Sinjai District, 2018

The table above shows that there are still 2 district heads in Sinjai District who have not attended the PIM III Training. According to Government Regulation Number 100 of 2000 on the Appointment of Civil Servants in a Structural Position stipulates that civil servants who will or have held structural positions shall follow and pass leadership education and training in accordance with the competencies set forth for such positions. Based on Article 7 of Government Regulation Number 100 of 2000 concerning the Appointment of Civil Servants in a Structural Position stipulates that civil servants who are appointed in structural positions have not followed and passed the education and training of leadership in accordance with the level of structural positions shall follow and pass education and leadership training no later than 12 (twelve) months from the date of the inauguration.

\section{Work experience:-}

A person's work experience needs to get a consideration in filling the position. The fact shows the longer a person works, the more experience the person has, the shorter the working period, the less experience you gain. Many work experiences provide skills and job skills. A person's work experience is sometimes more valued than the level of education. Experienced people can immediately complete the task and work. They only require relatively short training and instruction. Conversely, those who rely solely on their educational and degree backgrounds may not be able to do the tasks and jobs given to them quickly. Particularly regarding the requirements for filling the district head position, in addition to technical education of the government as one of the conditions there are also work experience, and long time a person has served in the government or like one of the conditions of filling the district head where the appointed head must have served in the Village, District head for a minimum of 2 years. When the district head leads a district head, the district head will not be distressed, because the district head is familiar with the office environment and has good relations with the community. The work between experienced and inexperienced district heads is different, this is a special consideration by the government in Sinjai District.

\section{Basic Consideration of District Government in Charging District Head Position:- Substance Law:-}

The substance of the law can be a very influential factor on the implementation of legislation, because the material laws contained in the articles greatly determine the effectiveness and implementation capabilities.

According to Mr. Firdaus ${ }^{15}$ that : "The filling of the district head position in Sinjai Regency is guided by Government Regulation Number 100 Year 2000 concerning the Appointment of Civil Servant in Structural Position, because the rules of filling the existing position in Law Number 5 Year 2014 on State Civil Apparatus have been issued in 2017 with the issuance Government Regulation Number 11 of 2017 on the Management of Civil Servants."

The above statement shows that the Personnel and Human Resource Development Agency of Sinjai District Apparatus is still using Government Regulation Number 100/2000 on the Appointment of Civil Servants in Structural Position as a reference.

\section{Personnel Agency and Human Resource Development Apparatus:-}

The law enforcement apparatus in this research is the Human Resources and Human Resource Development Agency of Sinjai District Apparatus who has the task of preparing and implementing the regional policy in the field of personnel. To carry out the task, the Human Resources Personnel and Human Resource Development Agency perform the functions:

1. The formulation of technical policy in the field of civil service based on the general policy stipulated by the Regent.

2. Provision of support for the implementation of regional government in the field of civil service.

3. Guidance and implementation of duties in the field of civil service.

15 Secretary of the Regional Personnel and Resources Development Agency of Sinjai District, the interview was held on February 9, 2018 at the Office of the Personnel and Resource Development Office of Sinjai District Apparatus. 
4. Management of general administration includes management, finance, personnel, equipment and problems.

5. Management of the agency's technical implementing unit.

6. Implementation of other tasks assigned by the Regent in accordance with its duties and functions.

Based on the results of research conducted revealed that the series of stages filling the district head position has been implemented well that is started by completing the list of candidates for district head. After the list of names of district head candidates is completed, the Bureau of Personnel conducts an examination of the terms of position and set forth in the form of a Councils of Position and Branch Considerations. Furthermore, the Office of Consideration of Position and Department held a meeting to discuss the issue of competence, seniority of rank, training and positions of experience. The result of the meeting of the Office of Consideration of Position and the Bureau shall be submitted in writing to the Regional Personnel Officer in the form of determining the order of the three selected candidates, then Regent shall choose one of them to make a decision letter. However, the fact that of the three proposed candidates, the officer of the regional civil service manager doesn't approve it, then the Regent proposes to the Office of Consideration of Position and the rank to review again.

\section{Cultural Law:-}

Legal culture aspect is one of the factors that influence the implementation of filling of district head position in Sinjai Regency that is still existence of paternalism culture, that is attitude which is too oriented upward. Paternalism is a system that places leadership as the most dominant party.

The elements of paternalism culture in Indonesia have been rooted into one of the obstacles to the creation of bureaucratic reform. One of them is in the case of filling district head positions are often done because it is based on the closeness of the relationship between the leadership with subordinates. Patterns of filling positions built based on the likes and dislikes are still being done in some local governments.

\section{Conclusions:-}

The filling of the district head position in Sinjai Regency is guided by Government Regulation Number 100 Year 2000 concerning the Appointment of Civil Servant in Structural Position which requires having the required job competence that is education factor and training of position and experience. In addition, Government Regulation Number 19 Year 2008 regarding the District Head requires a district head to master the governmental sciences proven by diploma / bachelor degree of government and has served in the village, urban village, or district head for at least 2 (two). The basis for consideration of district head positions is the legal substance, the Human Resources Personnel and Human Resource Development Agency, and the legal culture.

\section{References:-}

1. Achmad Ali. 2009. Menguak Teori Hukum dan Teori Pmasadilan, Jakarta : Kencana.

2. Agussalim. 2007. Pemerintahan Daerah Kajian Poltik dan Hukum, Bogor : Ghalia Indonesia.

3. Akhmad Syauki. 2013. Aspek Hukum Penataan Jabatan Struktural dalam Sistem Kepegawaian di Indonesia, Makassar : Universitas Hasanuddin

4. Aras Aira. 2013. Jurnal Analisis Kinerja Pemerintah Daerah Kabupaten Kampar Tahun 2013, Universitas Islam Negeri Sultan Syarif Kasim Riau.

5. Jimly Asshiddiqie. 2008. Pokok-Pokok Hukum Tata Negara Indonesia Pasca Reformasi. Jakarta : PT. Buana Ilmu Populer.

6. Logemann. diterjemahkan oleh Makkatutu dan Pangkerego. 1975. Tentang Teori Suatu Hukum Tata Negara Positif, (Over de Theori Van Een Stelling Staatsrecht). Ikhtiar Baru-Van Hoeve.

7. Marwati Riza. 2009. Perlindungan Hukum Pekerja Migran Indonesia Di Luar Negeri. As Publishing. Makassar.

8. Miftah Thoha. 2011. Birokrasi Pemerintah Indonesia di Masa Reformasi Cetakan Ketiga, Jakarta : Kencana Prenada Media Group.

9. Murhaini Suriansyah. 2012. Penegakan Hukum terhadap Kejahatan, Cetakan II, Laksbang, Grafika.

10. Pudja Pramana. 2009. Ilmu Negara. Yogyakarta : Graha Ilmu.

11. Ridwan HR. 2007. Hukum Administrasi Negara. Jakarta : PT. Raja Grafindo Persada.

12. Sirajuddin dkk. 2016. Hukum Administrasi Pemerintahan Daerah (Sejarah, Asas, Kewenangan, dan Pengawasan Penyelenggaraan Pemerintahan Daerah), Setara Pers, hlm. 136.

13. Soerjono Soekanto. 2008. Faktor-Faktor yang Mempengaruhi Penegakan Hukum. Jakarta : PT. Raja Grafindo Persada.

14. Sri Hartini. 2010. Hukum Kepegawaian di Indonesia. Jakarta : Sinar Grafika

15. Wibowo. 2012. Manajemen Kinerja, Rajawali Pers : Jakarta. 